\title{
The infection of Eustrongylides spp. in Pike Perch (Sander lucioperca L., 1758) (Teleostei: Percidae)
}

\author{
Tevfik Tansel TANRIKUL ${ }^{1} \quad$ Ezgi DİNÇTÜRK ${ }^{1 *} \quad$ Hakkı DERELI ${ }^{1}$ \\ ${ }^{1}$ Izmir Katip Celebi University, Faculty of Fisheries, 35620, Cigli, Izmir, Turkey. \\ (D): https://orcid.org/0000-0002-1684-7965, *iD: https://orcid.org/0000-0002-5826-2383, (D: https://orcid.org/0000-0002-1240-8922
}

How to cite: Tanrıkul, T.T., Dinçürk, E. \& Dereli, H. (2019). The infection of Eustrongylides spp. in Pike Perch (Sander lucioperca L., 1758) (Teleostei: Percidae). Anatolian Env. and Anim. Sciences, 4(2), 122-126.

Atıf yapmak için: Tanrıkul, T.T., Dinçtürk, E. \& Dereli, H. (2019). Sudak Balıkları (Sander lucioperca L., 1758) (Teleostei: Percidae)'nda Eustrongylides spp. Enfeksiyonu. Anadolu Çev. ve Hay. Dergisi, 4(2) 122-126.

\begin{abstract}
Eustrongylides sp. is the most significant freshwater fish zoonotic nematode and has a great importance for the environment, fishing and human health. The importance of this nematode is the ability of the capacity to infect carnivorous organisms and humans that feed on them. In this study, Eustrongylides spp. infection was determined from 51 samples of pike perch (Sander lucioperca L., 1758) between October 2015 and February 2016 from Lake Marmara (Manisa, Turkey). Each sample was observed and the prevalence of the infection was detected $100 \%$. The parasite samples were examined in Carl Zeiss 300 VP scanning electron microscope. The capsulated and encapsulated parasites were found in various muscles, abdominal cavity and on the internal organs. Furthermore, one sample was detected in the swim bladder without any harm. From scanning electron microscopy overviews, lips and papillae circles were detected on the anterior portion of the body as characteristics for diagnosis of the genus Eustrongylides.
\end{abstract}

Keywords: Eustrongylides spp., eustrongylidosis, food-borne parasite, nematodosis, Sander lucioperca.

\section{Sudak Balıkları (Sander lucioperca L., 1758) (Teleostei: Percidae)'nda Eustrongylides spp. Enfeksiyonu}

Öz: Eustrongylides spp., çevre, balıkçılık ve insan sağlığı açısından tatlı su balıklarının önemli bir zoonotik nematodudur. Bu nematodun önemi karnivor organizmaları ve onlarla beslenen insanları enfekte edebilme niteliğine sahip olmasıdır. Bu araştırmada Göl Marmara (Manisa, Türkiye)'dan Ekim 2015 - Şubat 2016 tarihleri arasında örneklenen 51 adet sudak (Sander lucioperca L., 1758) balığında Eustrongylides spp.'nin neden olduğu enfeksiyon tespit edilmiştir. Her bir örnekte enfeksiyonun prevalansı belirlenmiş ve incelenen örneklerin \% 100'ünde parazit görülmüştür. Parazit örnekleri Carl Zeiss 300 VP taramalı elektron mikroskobu (SEM) ile görüntülenmiştir. Kapsüllü ve kapsülsüz parazitler çeşitli kaslarda, karın boşluğunda ve iç organlarda tespit edilmiştir. Ayrıca hava kesesinde de herhangi bir lezyona neden olmayan parazit tespit edilmiştir. Taramalı elektron mikroskobu görüntülerinde Eustrongylides cinsinin teşhisi için vücudun ön kısmında dudaklar ve papilla halkaları tespit edilmiştir. 


\section{INTRODUCTION}

Lake Marmara which is located in the immediate proximity of Manisa City, Turkey has an importance in the area with industrial fishing that population benefitted as a valuable food resource. According to Ilhan \& Sarı, (2013) 15 taxa were reported belonging to the Atherinidae, Cyprinidae, Cobitidae, Percidae, Gobiidae, Poecilidae families in the lake and pike-perch (Sander lucioperca L., 1758) is one of the most commercial species with extensive economic value. The infection of Eustrongylides spp. being paratenic hosts on pike-perch due to its predator feeding regime (Bjelic-Cabrilo et al., 2013) while benthos-eating fish species, e.g. Gambusia neogobius and Cyprinidae family become intermediate hosts (Pazooki et al., 2007). From Danuba Canal, Serbia this parasite was registered from pike-perch meanwhile some reported cases from eel (Anguilla anguilla) (Romania), Carassius carassius (Iran), European catfish (Silurus glanis) (Serbia), sturgeon (Acipenser persicus) (Azerbaijan) and brown trout (Salmo trutta) (Norway) are known. Also its $3^{\text {rd }}$ and $4^{\text {th }}$ stages larvae were detected from various species of fish, aquatic birds, reptiles (Fauna Europaena, 2017; Molnar et al., 2006; Moravec, 1994), frog (Saglam \& Arikan, 2006) and dice snake (Carlssan et al., 2011).

The first-stage larvae passed by infected bird faeces and oligochetes such as Tubifex tubifex, Lumbriculus variegatus or Limnodrilus sp. (Bjelic-Cabrilo et al., 2013). Into the water, the egg hatches and finds the first host then fish feed on infested oligochetes, parasite reach $3^{\text {rd }}$ and $4^{\text {th }}$ stages larvae that would encyst on organs, peritoneal serosa and into the muscle (Urdes et al., 2015). The lesions caused by Eustrongylides excisus in the proventriculus wall could be heavy in order to the pathogenic effects of the nematodes coiled in a capsule that protects from the serosal surface (Bjelic-Cabrilo et al., 2013).

Eustrongylides spp. has great importance because of their capacity to infect carnivorous organisms and humans that feed on them (Mohammad et al., 2011). The infection of Eustrongylides spp. occur after ingestion of raw or poorly cooked fish meat (Ljubojevic et al., 2015). The nematodes cannot reach maturity in man, but remain in the fourth stage of larval development (Bjelic-Cabrilo et al., 2013). It causes gastritis and the perforation of intestines and the only possible way to cure this infestation is surgical removal of the larvae (Cole, 2009). Some reports from human cases are known that infected by Eustrongylides (Guerin et al., 1982; Eberhard et al., 1989).

The aim of the present work is to distinguish the presence of the parasite which is very important for human health in order to consume fish with an economic value in that area. It is substantial to increase public awareness for consuming fish meat containing infectious parasitic hazards.

\section{MATERIAL and METHOD}

51 samples of pike perch (Sander lucioperca) were collected from Lake Marmara, Manisa, Turkey $\left(38^{\circ} 37^{\prime} 02.5^{\prime \prime} \mathrm{N}, 28^{\circ} 01^{\prime} 03.1^{\prime \prime E}\right)$ between October 2015 and February 2016 and transferred to Izmir Katip Celebi University Faculty of Fisheries Fish Health Laboratory (Figure 1).

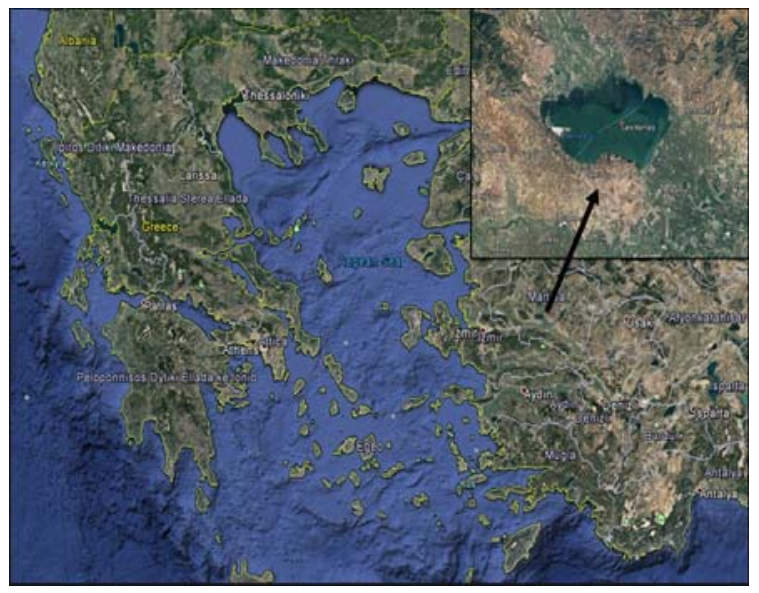

Figure 1. Lake Marmara.

The fish were measured $25.8-41.6 \mathrm{~cm}$ - and weighted 142.0-626.0 g and examined for parasites with the clinic and parasitological examination according to standard protocols (Hoffman, 1999).

After dissection, abdominal cavity and internal organs of each sample was examined. Nematodes were counted and collected from abdominal cavity, muscles, external and internal sides of the organs then identified according to Moravec 1994 and Anderson 2000.

After examination, they were fixed with $4 \%$ formaldehyde and stored. Samples were dehydrated according to Eisenback, (1986) and sputtered with gold with Quorum Q150 Res, examined in Carl Zeiss 300 VP scanning electron microscope from Izmir Katip Celebi University Central Research Laboratory.

\section{RESULTS}

From the examined fish, Eustrongylides spp. was determined from all the samples. The parasite was observed from bright red to reddish in colour. Eustrongylides infection was diagnosed in the muscle surrounding the abdominal wall, abdominal cavity, fatty tissue, dorsal muscle, swim bladder and between internal organs (Figure 2,3,4). The prevalence of the infection was detected at $100 \%$. From every sample, parasites were detected from various parts of the body. In addition, capsulated parasites were located in various muscles on the contrary of encapsulated samples which were mainly found in the abdominal cavity and on the internal organs. 


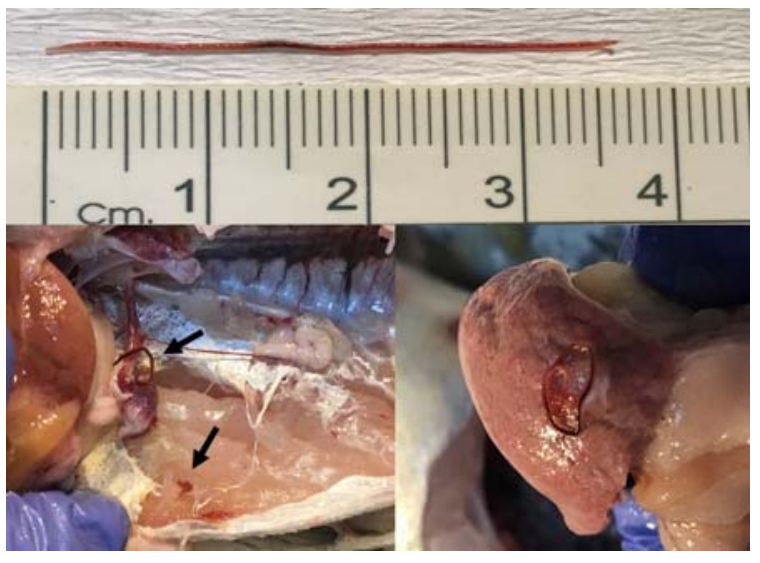

Figure 2. Sander lucioperca-body general appearance, capsuled larvae in muscle and in fatty tissue.

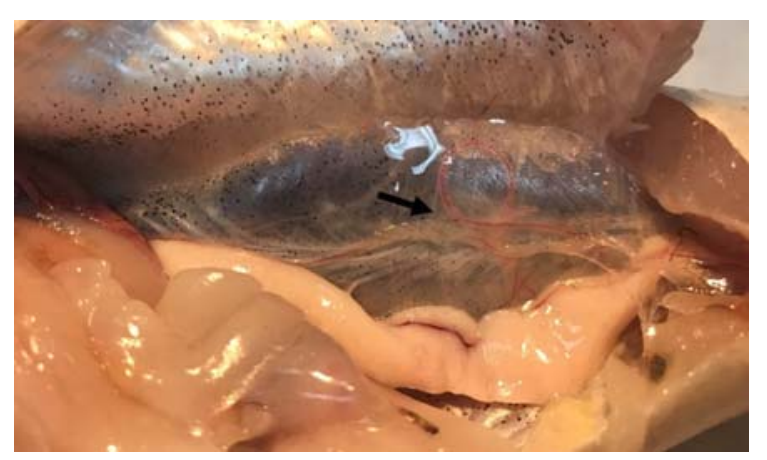

Figure 3. General appearance of Eustrongylides spp., free larvae in abdominal cavity and on liver.

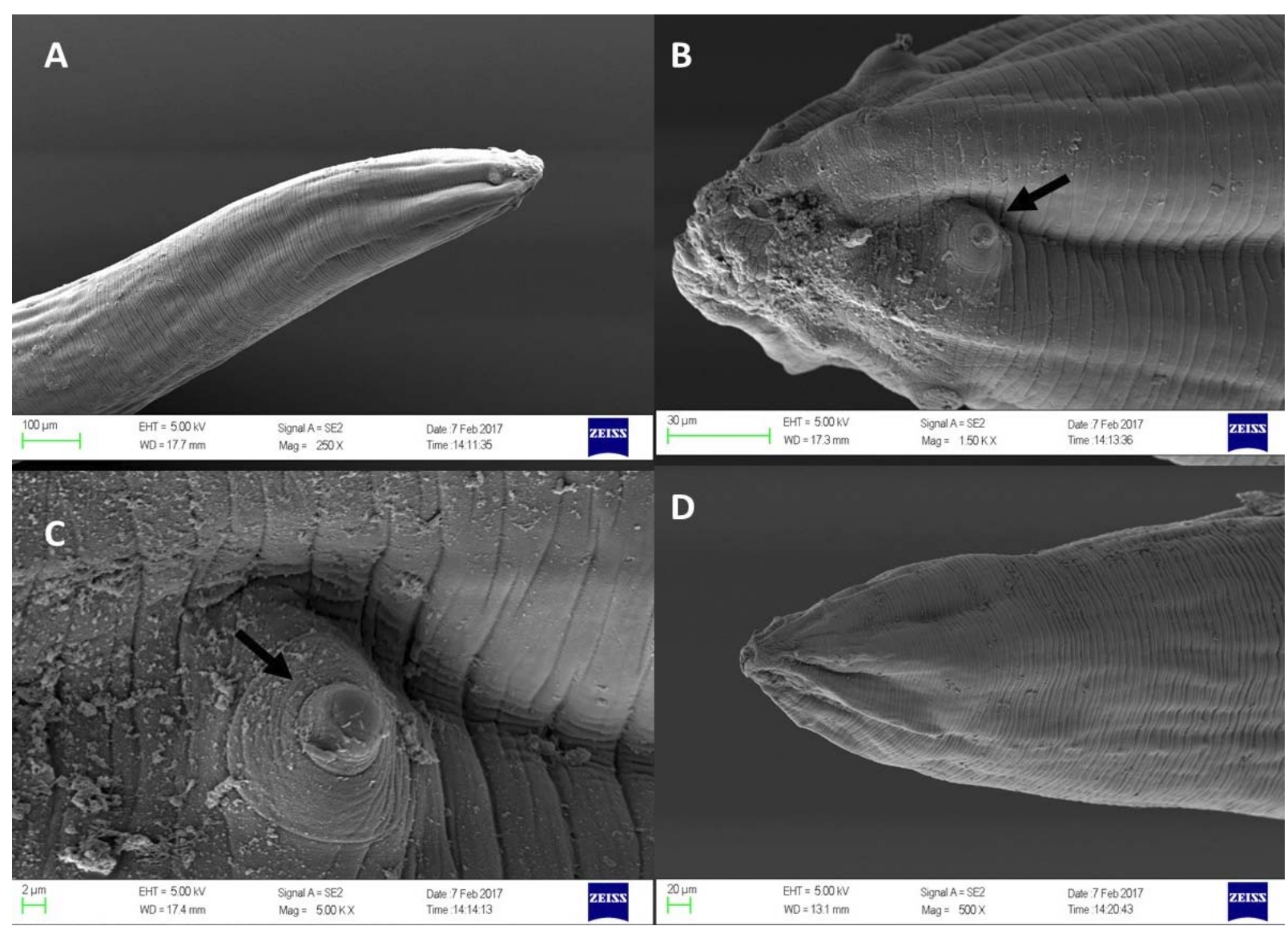

Figure 5. Scanning electron microscopy of the anterior portion of Eustrongylides spp. with different scales (A: $100 \mu \mathrm{m}$; B: $30 \mu \mathrm{m}$; C: $2 \mu \mathrm{m}$; D: $20 \mu \mathrm{m}$ ). Anterior portion showing lips and papillae circles.

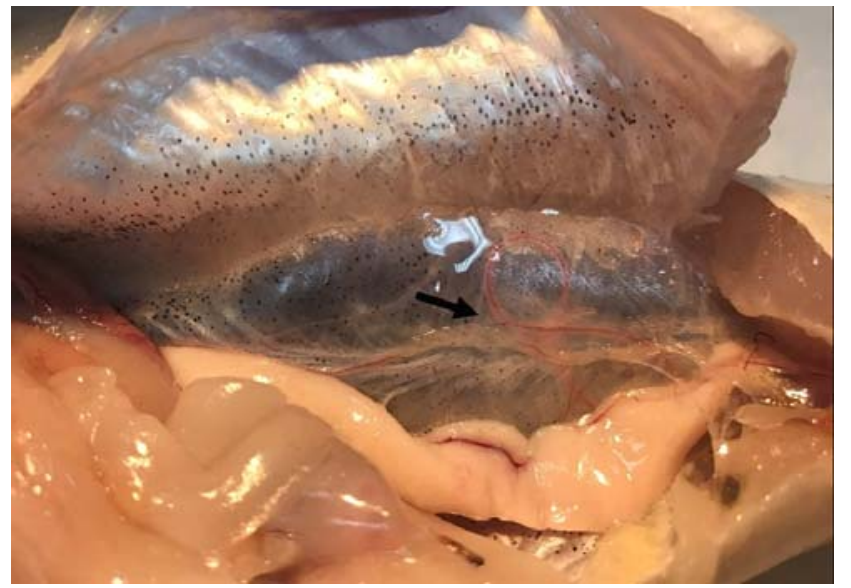

Figure 4. Eustrongylides spp. in swim bladder.

Interestingly the parasite that was found in the swim bladder cause no harm to the tissue and the swim bladder looked undamaged. The intensity of Eustrongylides spp. was ranged between 1-10 parasite/fish. From scanning electron microscopy overviews, lips and papillae circles were detected on the anterior portion of the body as characteristics for diagnosis of the genus Eustrongylides (Anderson, 2000; Lezama \& Sarabia, 2002) (Figure 5, 6). 


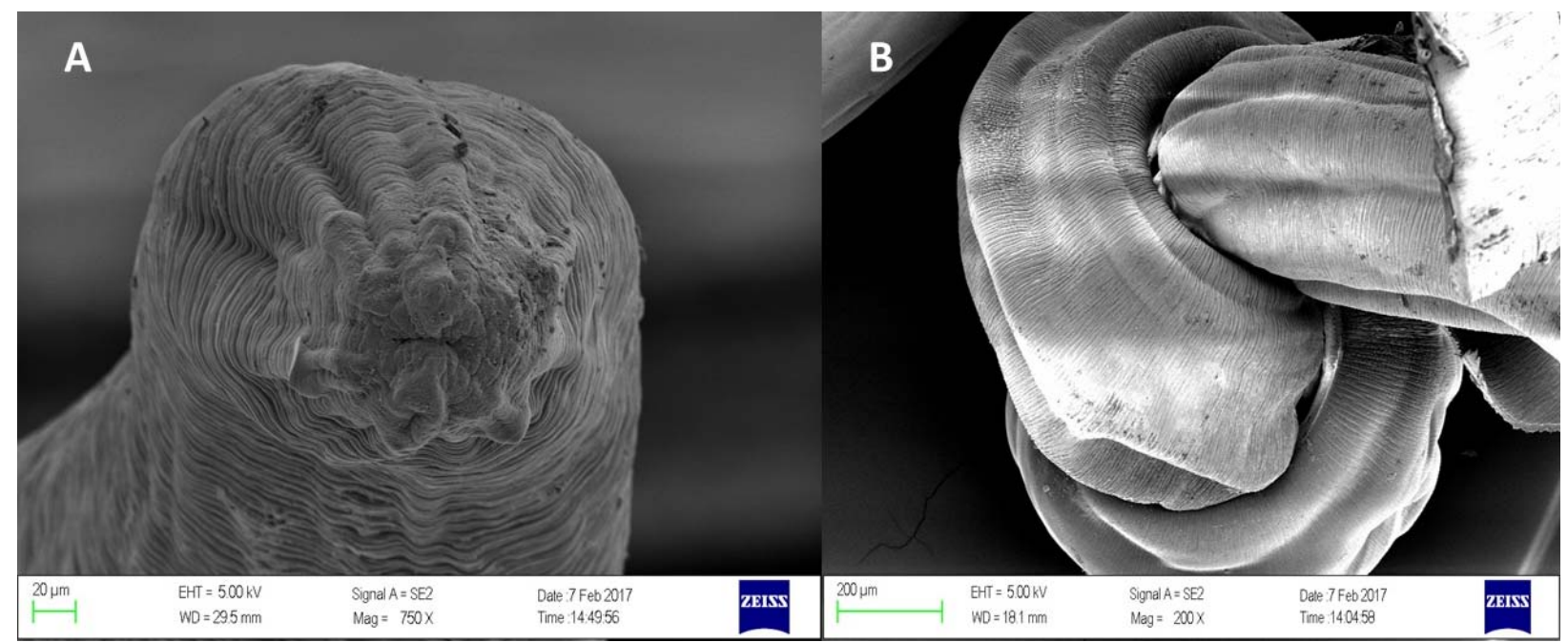

Figure 6. A: SEM overview of the anterior region of Eustrongylides spp. $(20 \mu \mathrm{m})$; B: Capsulated nematode with $200 \mu \mathrm{m}$ bar.

\section{DISCUSSION and CONCLUSION}

The genus Eustrongylides is reported from several geographical distribution such as Europe, Australia, Middle East, United States and Canada (Gora et al., 2013). From Turkey, it has declared from different locations and different species such as Eğirdir Lake in Carassius gibelio, Cyprinus carpio, Sander lucioperca and Atherina boyeri (Akcimen et al., 2014) and Lake Ulubat and Manyas in Gobius fluviatilis (Ozturk et al., 2001, 2002). In recent years the number of case reports referring to fish Eustrongylidosis not only has increased but also not paying any attention on the contrary to its importance. It is represented that in Beyşehir Lake (Konya, Turkey) Sander lucioperca is fed by Atherina boyeri (Apaydin Tarhan, 2012), which is a natural prey of perch and intermediate host of Eustrongylides. Our results demonstrated that this infection may occur by the feeding chain of pike perch based on the transmission of infection by feeding infected fish.

In Lake Marmara total pike-perch hunting was determined as $11655 \mathrm{~kg}$ in 2015 (Ministry of Food, Agriculture \& Livestock, 2016) and according to Ilhan and Sari, (2013) fishing is the main source of living in that area. As a commercial species, pike-perch has significant importance for fishing and consuming of fish meat. The presence of parasitic hazards causes safety concerns related to the consumption of raw or poorly cooked fish meat. The presence of Eustrongylides spp. in pike-perch is harmful to both natural environment in case of being potential for more species and human health to cause incidental/paratenic host relationships.

Eustrongylides spp. is reported as the most significant freshwater fish zoonotic nematode (Novakov et al., 2013; Bjelic-Cabrilo et al., 2013). Fish have confirmed as intermediate hosts that the larvae develop in muscles, body cavity and on visceral organs (Bjelic-Cabrilo et al., 2013). In this study, Eustrongylides spp. larvae were mostly found in the abdominal cavity, abdominal wall, muscles, in fatty tissue, between internal organs and unlike other reports in the swim bladder. Moravec, (1994) published that the larvae are capable of doing severe damage to various organs of the fish as large scars at the muscles, gastric and intestinal wall, complete destruction of the kidneys and inflammatory lesions.

Infected piscivorous fish are usually fed on infected prey and consumption of these fish seems to be becoming a considerable problem by its zoonotic potential (Urdeset al., 2015). Guerin et al., (1982) and Eberhard et al., (1989) were reported two different human cases that were identified as fourth-stage larvae of Eustrongylides. It was confirmed that the patients consume raw minnows while fishing and after severe abdominal pain, a pair of worms were detected from the abdominal cavity of each man (Eberhard et al., 1989). Mitchell et al., (2009) also claimed in humans who have consumed raw or undercooked fish, Eustrongylides spp. have produced gastritis and intestinal perforation. In this case, fish act as intermediate and paratenic hosts in the development of parasites' lifecycle (Ljubojevic et al., 2015). FDA suggested freezing, heating and adequate combination of salt content and storage time or hot smoking to kill parasites (FDA, 2001). Also, Murrell, (2002) published that, environmental control of surface water, hygienic aquaculture and control or elimination of the first intermediate hosts could help to control parasite infection originating from freshwater.

In conclusion, Eustrongylides spp. which belong to the group of food-borne parasites has great importance for both fish health and human consumption. It recently becomes a considerable problem for the natural environment, commercial fishing and human health in Turkey but more studies are needed to eliminate and minimize this problem. Its geographical distribution, relations with hosts and the place in the food chain should be clarified in order to avoid the hazards to human health and environment. 


\section{REFERENCES}

Akcimen, U., Emre N., Bulut, C., Cinar, S. \& Yagci, A. (2014). An investigation on Eustrongylides excisus (Jagerskiöld, 1909) parasite in fish of Lake Eğirdir. V. Eastern Anatolia Region Fisheries Symposium, May 31- June 02, Elazı $\breve{g}$.

Anderson, R.C. (2000). Nematode parasites of vertebrates: Their development and transmission, $2^{\text {nd }} \mathrm{ed}$. Wallingford: $\mathrm{CAB}$ International. Doi: 10.1079/9780851994215.0000

Apaydin Tarhan, A. (2012). Beyşehir Gölü sudak (Sander lucioperca L., 1758) populasyonunun besinleri ve beslenme alışkanlıklarının incelenmesi. Süleyman Demirel Üniversitesi Fen Bilimleri Enstitüsü, Doktora Tezi.

Bjelić-Čabrilo, O., Novakov, N., Ćirković, M., Kostić, D., Popović, E., Aleksić, N. \& Lujić, J. (2013). The first determination of Eustrongylides excisus Jägerskiöld, 1909-larvae (Nematoda: Dioctophymatidae) in the pikeperch Sander lucioperca in Vojvodina (Serbia). Helminthologia, 50(4), 291-294. Doi: 10.2478/s11687013-0143-1

Carlsson, M., Karvemo, S., Tudor, M., Sloboda, M., Mihalka, A.D., Ghira, I., Bel, L. \& Modrý, D. (2011). Monitoring a large population of dice snake at lake Sinoe in Dobrogea, Romania. Mertensiella, 18, 237-244.

Cole, R.A. (2009). Eustrongylidosis. In: Field manual of wildlife diseases-General Field procedures and diseases of birds,

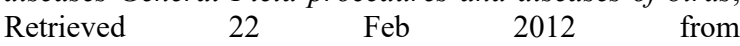
www.nwhc.usgs.gov/publications/field_manual/chapter_2 9.pdf

Eberhard, M.L., Hurwitz, H., Sun, A.M. \& Coletta, D. (1989). Intestinal perforation caused by larval Eustrongylides (Nematoda: Dioctophymatoidae) in New Jersey. The American Journal of Tropical Medicine and Hygiene, 40(6), 648-650.

Eisenback, J.D. (1986). A comparison of techniques useful for preparing nematodes for scanning electron microscopy. Journal of Nematology, 18(4), 479.

Fauna Europaea (2017). Erișim tarihi: September 2016, URL https://fauna-eu.org/cdm_dataportal/taxon/6ef0cf77-ea104c5a-a637-2cf67bcb94ec

FDA. (2001). Fish and Fisheries Products Hazards and Controls Guidance. 3rd Edition. Food and Drug Administration, Center for Food Safety and Applied Nutrition, Washington, DC, USA; 2001, URL http://www. fda.gov/Food/GuidanceRegulation/GuidanceDocumentsR egulatoryInformation/Seafood/ucm2018426.htm

Guerin, P.F., Marapendi, S. \& Mc Grail, L. (1982). Intestinal perforation caused by larval Eustrongylides. Morb. Mort. Week. Rep, 31, 383-389.

Hoffman, G.L. (1999). Parasites of North American Freshwater Fishes, Second Edition, Comstock Publishing Associates, Cornell University Press, New York.

Ilhan, A. \& Sari, H.M. (2011). Marmara Gölü balık faunası ve balıkçılık faaliyetleri, Fish fauna and fisheries activities in Lake Marmara. Ege Journal of Fisheries and Aquatic Sciences, 187. Doi: 10.12714/egejfas.2013.30.04.08

Lezama, J.R. \& Sarabia, D.O. (2002). Histological lesions in skeletal muscle, caused by Eustrongylides $s p$. (Nematoda: Dictiophymatoidae) larvae in edible frogs from Lake Cuitzeo, in The State of Michoacan, in Mexico. Veterinaria (Mex); 33(3), 335-341.

Ljubojevic, D., Novakov, N., Djordjevic, V., Radosavljevic, V., Pelic, M. \& Cirkovic, M. (2015). Potential parasitic hazards for humans in fish meat. Procedia Food Science, 5, 172-175. Doi: https://doi.org/10.1016/j.profoo.2015. 09.049 .
Mitchell, A.J., Overstreet, R.M. \& Goodwin A.E. (2009). Eustrongylides ignotus infecting commercial bass, Morone chrysops female X Morone saxatilis male, and other fish in the Southeastern USA. Journal of Fish Disease; 32, 795-99. Doi: 10.1111/j.13652761.2009.01051.x

Mohammad, R., Iraj, M., Mahzad, A.M., Behyar, J., Bagher, A.F. \& Saeed, S.S. (2011). Occurrence and intensity rate of internal metazoan parasites in Rutilus frisii kutumand the first report of Dioctophyma renale (Nematoda: Dioctophymidae) in Iran. World Journal of Zoology, 6(1),91-97.

Molnar, K., Buchmann, K. \& Szekely, C. (2006). Ph Nematoda, In: Fish disease and disorders, vol. I, 417-430, 2nd edition, P.T.K. Woo, Univ. of Guelph, Canada.

Moravec, F. (1994). Parasitic nematodes of freshwater fishes of Europe. Kluwer Academic Publisher, 470p.

Murrell, KD. (2002). Fishborne zoonotic parasites: epidemiology, detection and elimination. lactic acid bacteria in fish preservation. In: Bremner HA, editor. Safety and quality issues in fish processing. New York: Woodhead Publishing Ltd. CRC press; 2002. p. 114-141.

Novakov, N., Bjelic-Cabrilo, O., Cirkovic, M., Jubojevic, D., Lujic, J. \& Davidov Jovanovic, I., (2013). Eustrongylidosis of european catfish (Siluris glanis). BulgarianJournal of Agricultural Science, 19(1), 72-76.

Ozturk, M.O., Aydoğdu, A. \& Doğan, I. (2002). The occurrence of the helminth fauna in sand goby (Gobius fluviatilisPallas, 1811) from Lake Uluabat, Turkey. Acta Veterinaria Belgrade, 52, 381-392. Doi: 10.2298/AVB0206381O

Ozturk, M.O., Oguz, M.C. \& Altunel, F.N. (2001). An investigation on the metazoan parasites of goby (Gobius fluviatilis L) in Lake Manyas and two new records for helminth fauna of Turkey. Acta Parasitologica Turcica, 25, 88-93.

Pazooki, J., Masoumian, M., Yahyazadeh, M. \& Abbasi, J. (2010). Metazoan parasites from freshwater fishes of northwest Iran. Journal of Agricultural Science and Technology, 9, 25-33.

Sağlam N. \& Arıkan, H. (2006). Endohelminth fauna of the marsh frog Rana ridibunda from Lake Hazar, Turkey. Diseasesof Aquatic Organisms, 72, 253-260. Doi: 10.3354/dao072253

Urdes, L.D., Marin, M.P., Diaconescu, C., Nicolae, C.G. \& Hangan, M. (2015). First case report of eustrongylidosis in eel (Anguilla anguilla) populations inhabiting Danube Delta Lakes. Agriculture and Agricultural Science Procedia, 6, 277-280. Doi: https://doi.org/10.1016/j. aaspro.2015.08.072

*Corresponding author's:

Ezgi DİNÇTÜRK

Izmir Katip Celebi University, Faculty of Fisheries, Balatçık Mahallesi Havaalanı Şosesi No:33/2 Balatçık, 35620 Cigli, Izmir, Turkey.

$\triangle$ E-mail: ezgi.dincturk@ikc.edu.tr,

ORCID: https://orcid.org/0000-0002-5826-2383 